\title{
SCIENTIFIC ATTITUDE OF HIGH SCHOOL STUDENTS
}

KEY WORDS: Scientific attitude, high school students

\section{P. H. Jebalin Paul}

\section{Dr. v. S. Mini} Kumari*
Research Scholar, N. V. K. S. D. College of Education, Attoor, Kanyakumari District \& Assistant Professor of Physical Science, Christian College of Education, Marthandam

Associate Professor in Biological Science, N. V. K. S. D. College of Education, Attoor, Kanyakumari District, Tamilnadu. *Corresponding Author

The main objective of this study was to find out the scientific attitude of high school students. An attempt was also made to study the influence of background variables like gender, locality and type of school management on scientific attitude of high school students. The study revealed that majority of the high school students have medium level of scientific attitude. It was also found that there is no significant difference in the scientific attitude of high school students with respect to gender and type of school management. But significant difference exists between the rural and urban high school students in their scientific attitude.

\section{INTRODUCTION:}

Science has revolutionised our way of living. Our thinking, attitudes, interests, outlook etc. have undergone tremendous change due to the development of science and technology. Science is one of those human activities that man has created to gratify human needs and desire. According to Fitzpatrick "Science is a cumulative and endless series of empirical observations which result in the formation of concepts and theories, with both concepts and theories being subject to modification in the light of further empirical observations. Science is both a body of knowledge and the process of acquiring it"' (Mohan, 2004).

Scientific attitudes are the most important outcomes of science teaching. Scientific attitude is a set of attitudes and values possessed by an individual, which are commonly used in solving problems in a scientific way (Ahmad, 2011). Scientific attitude is defined as a set of emotionally toned ideas about science, scientific methods and related directly or indirectly to the course of action in the literature of science education (Mishra and Singh, 2014). A person with scientific attitude possess qualities such as intellectual curiosity, passion for truth, respect for evidences, open mindedness, unbiased judgement and belief in cause-effect relationship in science.

\section{Review of related studies:}

Prasanthi(2019) conducted a study on scientific attitude among secondary school students in model school. The findings of the study revealed that the students were good in the domains of curiosity, open mindedness, faith in scientific method, critical mindedness, cause and effect relationship, seeking evidence, suspended judgement, objectivity and aversion to superstition.

Jampannanavar (2018) studied the relationship between scientific attitude and academic achievement in science among secondary school students. The study revealed that there is high correlation between scientific attitude and academic achievement in science of secondary school students.

Veliappan and Nambikkai (2018) investigated the attitude towards science of higher secondary students in Puducherry region. The findings of the study were: $i)$ There is significant difference among government, aided and un-aided higher secondary school students in their attitude towards science. ii) There is significant difference among pure science, mathematics and computer science group of higher secondary students in their attitude towards science. iii) There is significant difference among rural, semi urban and urban higher secondary students in their attitude towards science.

\section{Need and significance of the study}

One of the major objectives of teaching science is the development of scientific attitude among the students. The development of scientific attitude makes pupil open minded, helps him to make critical observations, develops intellectual honesty, curiosity, unbiased and impartial thinking etc. Scientific attitude is the most important outcome of science teaching. Though some educationists view, scientific attitude as a by-product of teaching science, yet a majority of educationists consider it to be major product or the aim of science teaching (Sharma, 1999).

A person having scientific attitude is found to have love for the exploration of truth by adopting true means for such exploration and believing in the results of such true findings. The main aim of science teaching should be the development of knowledge and inculcation of proper scientific attitude among students. In the present educational system though students' knowledge in science increase, they fail to develop proper scientific attitude. So it is necessary to encourage the students to develop scientific attitude. The present study has been undertaken to find out the level of scientific attitude among high school students.

\section{Objectives of the study}

1. To study the level of scientific attitude of high school students.

2. To find out whether there is any significant difference in the mean scores of scientific attitude of high school students with respect to the background variables gender, locality and type of management of the school.

\section{Hypotheses}

1. There will be significant difference in the mean scores of scientific attitude of male and female high school students.

2. There will be significant difference in the mean scores of scientific attitude of rural and urban high school students.

3. There will be significant difference in the mean scores of scientific attitude of high school students studying in government, aided and self-financing schools.

\section{Methodology}

The normative survey method was adopted for conducting the present study. The sample consisted of 200 high school students studying in different schools of Kanyakumari District. 
The tool used for the collection of data was "Shailaja Bhagawat Scientific Attitude scale (2006)" (SBSAS) constructed by Shailaja Bhagwat. The collected data were analysed by using the statistical techniques such as percentage, arithmetic mean, standard deviation and $t$ test.

\section{RESULTS AND DISCUSSION}

Table: 1 Percentage wise distribution of sample according to different levels of Scientific Attitude

\begin{tabular}{|c|c|c|}
\hline Scientific Attitude & Count & Percent \\
\hline Low & 37 & 18.50 \\
\hline Medium & 123 & 61.50 \\
\hline High & 40 & 20.00 \\
\hline Total & 200 & 100.0 \\
\hline
\end{tabular}

From the above table it is seen that the percentages of samples according to low, medium and high level of scientific attitude were $18.5 \%, 61.5 \%$ and $20 \%$ respectively. This indicates that the majority of high school students have medium level of scientific attitude.

Table: 2 Comparison of Scientific Attitude based on gender

\begin{tabular}{|l|l|l|l|l|l|c|}
\hline Gender & Mean & SD & $\mathrm{N}$ & $\mathrm{t}$ & $\mathrm{p}$ & $\begin{array}{c}\text { Level of } \\
\text { significance }\end{array}$ \\
\hline
\end{tabular}

\begin{tabular}{|c|c|c|c|c|c|c|}
\hline Male & 133.78 & 22.18 & 91 & 0.039 & 0.969 & $\begin{array}{c}\text { Not } \\
\text { significant }\end{array}$ \\
\hline Female & 133.90 & 21.28 & 109 & & &
\end{tabular}

From Table- 2 it is seen that the obtained $t$-value $(t=0.039)$ is not significant at any level. This result indicates that there is no significant difference between the male and female high school students in their scientific attitude. So it can be concluded that gender has no influence on the scientific attitude of high school students.

Table: 3 Comparison of Scientific Attitude based on locality

\begin{tabular}{|c|c|c|c|c|c|c|}
\hline Locality & Mean & $\mathrm{SD}$ & $\mathrm{N}$ & $\mathrm{t}$ & $\mathrm{p}$ & $\begin{array}{c}\text { Level of } \\
\text { significance }\end{array}$ \\
\hline Rural & 139.97 & 21.57 & 103 & 4.314 & 0.000 & $\begin{array}{c}\text { Significant at } \\
0.01 \text { level }\end{array}$ \\
\hline Urban & 127.34 & 19.83 & 97 & & & \\
\hline
\end{tabular}

From table- 3 it is seen that the obtained $t$ - value $(t=4.314)$ is significant at 0.01 level. This result indicates that there is significant difference between the rural and urban students in their scientific attitude. The mean score of the rural students (139.97) is higher than that of the urban students (127.34). So, it can be concluded that locality has influence on the scientific attitude of high school students.

Table: 4 Comparison of Scientific Attitude based on type of management

\begin{tabular}{|c|c|c|c|c|c|c|c|c|c|}
\hline $\begin{array}{c}\text { Type of } \\
\text { management }\end{array}$ & Mean & SD & Source & $\begin{array}{c}\text { Sum of } \\
\text { squares }\end{array}$ & df & $\begin{array}{c}\text { Mean } \\
\text { square }\end{array}$ & F & p & $\begin{array}{c}\text { Level of } \\
\text { significance }\end{array}$ \\
\cline { 1 - 7 } Government & 138.13 & 22.27 & Between GP & 1982.79 & 2 & 991.40 & 2.142 & 0.120 & Not significant \\
\cline { 1 - 6 } Aided & 131.25 & 21.55 & Within GP & 91195.40 & 197 & 462.92 & & & \\
\hline Self-financing & 135.33 & 18.73 & Total & 93178.19 & 199 & & \\
\end{tabular}

From table-4 it is seen that the obtained F-value (2.142) is not significant at any level. This result indicates there is no significant difference in the mean scores of scientific attitude of high school students studying in government, aided and self-financing schools. So it can be concluded that the type of school management has no influence on scientific attitude of high school students.

\section{Findings}

1. Majority of the high school students have medium level of scientific attitude.

2. There exists no significant difference between the male and female high school students in their scientific attitude.

3. There exists significant difference between the rural and urban high school students in their scientific attitude.

4. There exists no significant difference between the high school students studying in government, aided and selffinancing schools in their scientific attitude.

\section{CONCLUSION:}

The study revealed that the majority of high school students have medium level of scientific attitude. It was also found that gender and type of school management have no influence on scientific attitude of high school students but the locality has influence on scientific attitude. Since the high school students have only medium level of scientific attitude, the teachers should take necessary steps to develop scientific attitude among students. The teacher can manipulate various situations to infuse certain characteristics of scientific attitude among the students. The teacher should develop desirable atmosphere in the class for the development of scientific attitude. The major responsibility for developing scientific attitude among the students lies on the science teacher. Without developing scientific attitude among students the aims of teaching science cannot be achieved.

\section{REFERENCES:}

1. Ahmad Jasim, (2011). Teaching of Biological Science. New Delhi: PHI learning Pvt Ltd.

2. Joshith, (2016). Pedagogy of Physical science. Chennai:Polymath Press.

3. Panneerselvam.,Muthamizhselvan, (2015). The Secondary School students in relation to Scientific Attitude and Achievement in Science,IOSR Journal of Research \& Method in Education, 5(8), 5-8.

4. Paulmathi Lucas, 2016. A study of scientific attitude and academic achievement in science of secondary school students, AIJRELPLS, 1(1), 68-74.

5. Prasanthi, (2019). Scientific attitude among secondary school students in model schools. Edutracks, 18(8).

6. Preeti Mishra and Uday Singh, (2014). Study of scientific attitude of B.Ed. and B.Ed(special) pupil teachers. An International peer reviewed SRIIS, 2(13) 1815-1822.

7. Radha Mohan, (2004), Innovative Science Teaching, New Delhi PHI learning Pvt.Ltd.

8. Sharma R.C.,(1999), Modern science teaching, New Delhi, Dhanpatri publishing company.

9. Veliappan and Daisy Nambikkai, (2018), Attitude towards science, A study among higher secondary students in Puducherry region, Research and reflections in Education, 16(2), 21-27.

10. Jampannavar Yadwad, (2018), A study of relationship between scientific attitude and academic achievement in science among secondary school students, Review of research 7(4). 